many cases the comparison would undoubtedly prove interesting. But fortunately the descriptions are so good that the student loses less than might be expected, and the results are very valuable, not only to the farmers for whom they were intended, but also to the student of soil problems all over the world.

E. J. R.

\section{THE SCIENTIFIC WORK OF A SCHOOL OF TECHNOLOGY.}

$T^{H}$

E eighth volume of the Record of Investigations undertaken by members of the Manchester Municipal School of Technology, covering technological researches carried out during the year 1914, has just been issued. It is a highly interesting record of work accomplished, and is comprised in $25^{8}$ quarto pages replete with explanatory diagrams and photographs illustrative of the text. This attempt to put upon permanent record the investigations conducted by members of the staff and by advanced students was begun in 1905 , and has now extended to 2346 pages, and in its eight volumes covers researches carried out since the year Igoo in all departments of the school, including pure and applied mathematics, mechanical engineering, physics and electrical engineering, pure and applied chemistry and metallurgy, the science and practice of sanitation and building, textile manufacture, and the photographic and printing industries.

For investigations in all these important departments of industrial enterprise the school is exceptionally well equipped, and it has, moreover, had the assistance of many enlightened manufacturers, and in this connection many considerable extensions are in contemplation, only awaiting the conclusion of the war to give them full effect. Meanwhile new laboratories for advanced training and research in the subject of coal-tar chemistry in its bearing upon the dye-stuff industry have been opened under the charge of Prof. A. G. Green, of the University of Leeds, with the help and advice of Dr. E. Knecht, the professor of chemical technology, thus giving full opportunity, not only for the efficient training of chemists for the growing demands of the organic chemical industries, but for the establishment of a school of research for the chemistry of dyes and allied substances employed in industrial chemistry.

Many of the articles and researches published in these journals have also appeared in the scientific and technical Press. Lists are also given of important papers read in connection with the various technical societies connected with the school, including the Engineering Society, the Day Students'. Chemical Society, the Textile Society, which itself publishes an important journal; the Printing Crafts Guild, and the Bakery and Brewing Students'Societies, together with the titles of fifty-four theses prepared by graduate students in technology for the degree of M.Sc.Tech. in the University of Manchester. Lists also appear of the titles of nearly fifty volumes of technical works issued by members of the staff since 1900 .

The eighth volume of the journal under review contains, among other articles of value, interesting papers concerned with the applications of chemical science, such as those on vulcanising, industrial gas-burning, the action of strong nitric acid upon cotton cellulose and of sulphuretted hydrogen upon sodium hydrosulphite, together with papers on the dilution limit of inflammability of gaseous mixtures and on the ignition of gaseous mixtures by the electric discharge. Not the least valuable paper is one entitled "A Contribution to the History of Dyeing in Scotland," beirig a sequel to one in vol. vii. of the journal on the history of dyeing suggested by a remark of the late Prof. Meldola in his presidential address of I9 Io to the Society of Dyers and Colourists on "The Antiquity of Tinctorial Art": "I have in mind the desirability of technical societies such as ours including in their work the antiquarian side of their subject. This is, as a rule, -neglected. Nevertheless, it is desirable to secure records of the past with respect to ancient industries, and the experts in any particular subject are assuredly the right people ts undertake such work." Other important articles is. the current number deal with researches on the ultimate endurance of steel and, of the results of experiments with lathe-finishing tools, a continuation of valuable experiments and investigations begur in the school so far back as 1903 on high-speed tool steels and cutting tools, which are even now under investiga. tion; on modern boiler-room practice and the prevention or abatement of smoke; on the effect of structure on the strength and wearing qualities of cloth, copiously illustrated; on a null method of testing vibration galvanometers; and on the commutation of large continuous-current generators and rotary converters under heavy-load conditions.

The school is thus "an excellent example of the kind of work which the engineering colleges and the higher technical schools in this country ought to undertake, and must be prepared to perform, if they are to occupy the place of similar institutions abroad in the very important matter of practical research, not merely as teaching young men the elements of technical science, but also as establishments where industrial experiments can be carried out on a practical scale." It only remains to say, as exhibiting the great resources of this school, that the journal has been admirably printed and its illustrations prepared at the school press.

J. H. R.

\section{PHYSIOLOGY AT THE BRITISH ASSOCIATION.}

THE attendance of physiologists at the Newcastle 1 meeting was comparatively small, but there was a good programme, and several of the papers elicited considerable discussion. Prof. Cushny, the president of the section, took a pharmacological subject for his address. Reports of research committees were then presented, and Prof. Waller exhibited a simple apparatus for the administration of known percentages of chloroform. The recent modifications suggested by the extensive use of the instrument were described.

A series of lantern-slides illustrating the action of pituitary extract on the secretion of cerebro-spinal fluid was shown by Prof. Halliburton. The increased secretion is claimed by him to be an indirect result of the extract, the immediate cause being ascribed to stimulation of the cells of the choroid plexus by an increased quantity of $\mathrm{CO}_{2}$ in the blood.

Prof. W. H. Thompson detailed the results of further investigations into the formation of arginine and creatine. An interesting paper by Prof. Cushny on the secretion of urea and sugar by the kidney was the outcome of a repetition of Heidenhain's experiments. with this difference, that urea in some experiments, and sugar in others, were injected instead of a dye into the blood of an animal after transection of its spinal cord. Analysis of the kidneys after a suitable interval showed no increase of urea or sugar in them above the normal, and there was therefore no accumulation of these substances in the cells of the convoluted tubules.

Prof. Herring gave the results of several series of experiments in which white rats had been fed on small

NO. 2453, VOL. 98] 